\title{
Steve Biko Christ-figure: A black theological Christology in the Son of Man film
}

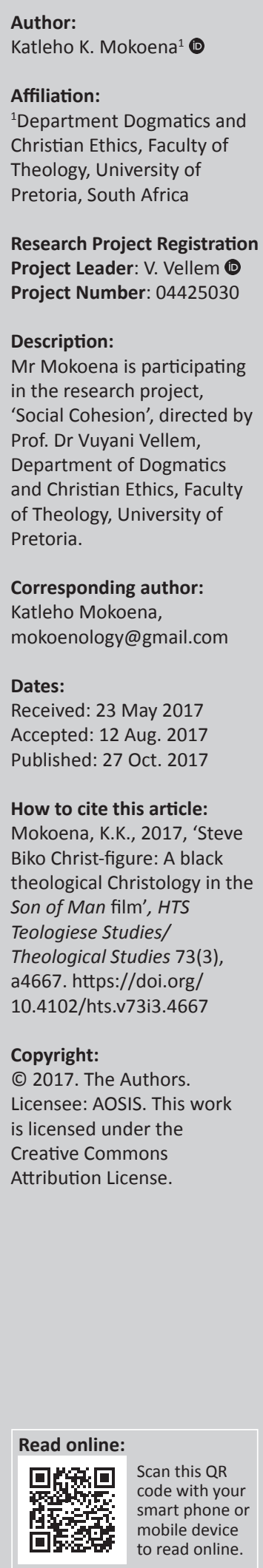

Author:

Affiliation:

Department Dogmatics and

Pretoria, South Africa

Research Project Registration Project Leader: V. Vellem (1)

Description

Mr Mokoena is participating in the research project,

'Social Cohesion', directed by rof. Dr Vuyani Vellem, and Christian Ethics, Faculty of Theology, University of Katleho Mokoena,

Accepted: 12 Aug. 2017

Published: 27 Oct. 2017

Mokoena, K.K., 2017, 'Steve

Son of Man film', HTS

Teologiese Studies/

4667. https:/

10.4102/hts.v73i3.4667

Copyright:

Licensee: AOSIS. This work

is licensed under the

Creative Commons

Attribution License.

mobile device
to read online.
Son of Man (2006) is the first Jesus film to be produced in South Africa and the first Jesus film with an all-black cast amongst all films about the life of Jesus. Son of Man retells the story of Jesus from the pre-1994 South African context and the transition to democracy. The film portrays a Jesus who is concerned about social justice and seeks to dismantle systems that perpetuate and maintain subjugation, oppression, discrimination and marginalisation. The film reinforces the ideology of black consciousness and the praxis of black theology creatively and artistically through film. Jesus in Son of Man embodies the life of Stephen Bantu Biko, and Steve Biko is thus given a Christ-figure around four things: non-violence, ideology, disappearance and death. A black Christological perspective is used to analyse the nature of Jesus Christ in Son of Man.

\section{Introduction}

Son of Man (2006) is the first film in the Jesus-film genre with an entirely black cast, including the leading role of a black Jesus. Historically, the Jesus film genre has been produced by western filmmakers with a white cast in ancient film sets, portraying how the world of Jesus would have been in first century Palestine. Reinhartz (2007:48) describes the white male cinematic Jesus as almost always of medium height, with medium brown hair, a short brown beard and piercing blue eyes. Son of Man, however, places the narrative of Jesus in the contemporary South African context. Jesus is black, bald-headed, speaks isiXhosa and upholds isiXhosa culture and tradition. Son of Man is a transcultural narrative of Jesus, relating the Gospel narrative(s) to the black experience in South Africa. Son of Man diminishes the perception that the image of Jesus can only be portrayed as western. It reinforces the ideology of black consciousness and the praxis of black theology creatively and artistically through film. Chattaway (2006) states that in adapting the story for film, Dornford-May said he was not interested in studying other retellings of the life of Jesus. Instead, he was drawn to the accounts of Steve Biko. Steve Biko is thus given a Christ-figure around four things: non-violence, ideology, disappearance and death.

\section{Biko Christ-figure}

\section{Non-violence}

Initially, the African National Congress (ANC) attempted non-violent means to attain land and freedom since 1912. The Pan Africanist Congress (PAC) is a breakaway party from the ANC because of ideological differences regarding the Freedom Charter in 1955. It was also a non-violent political party until the Sharpeville Massacre on 21 March 1960. Both ANC and PAC decided to approach the liberation struggle by responding with violence. Military wings for the political parties were formed: uMkhonto we Sizwe (MK) for the ANC and the Azanian People's Liberation Army (APLA) for the PAC. Even when both the political parties were banned, they continued the armed struggle from the underground in exile. The black consciousness movement operated during the banning of ANC and PAC. Biko (1978:151) states that black consciousness was committed to achieving their goals through non-violent means. Every programme under the black consciousness umbrella always maintained a peaceful approach to the oppressive system. They understood their legal limitations of their operation, putting their lives in danger by being banned and arrested. Even so, the belief was that the white person will eventually listen to the black voice without using violent means. The main goal was liberating the black person from an inferiority complex and to have black pride. The other is for the black person to be self-dependent economically and have self-determination of their own destiny. More (2004:213) explains that the black consciousness movement had a two-phased strategy. Phase 1 was psychological liberation and phase 2 was physical liberation. At the time, a militant movement was suicidal and would inevitably be defeated by the apartheid regime. Black consciousness, on the other hand, survived and gained support from white liberals as well as international exposure through its non-violent 
means. Biko as an individual believed in verbal communication when confronted as he would be 'bound' to communicate verbally also, but would respond differently when they adopt 'rough stuff'. Biko was not afraid to hit back when being hit; recalling an incident when he was arrested, he says, 'we had a boxing match the first day I was arrested. Some guy tried to clout me with a club. I went into him like a bull' (Biko 1978:173). Biko's viewpoint was that the only way to deal with policemen was to be as unhelpful as possible and not allow them to carry out their programme of fear and intimidation faithfully.

Jesus in Son of Man also used the method of non-violence as a means for liberation when he asked his disciples to handover their guns because 'we do not need weapons to fight this battle'. Jesus conscientised the people on the existential situations in the community like poverty, overcrowding and lack of education of which the occupiers and elders blame the people for the unrest in Judea. Jesus emphasised 'we must prove to them (the occupiers) that we are committed to non-violent change' in dealing with poverty, epidemics and thuggery. Human life is very important and violence should not be used to have long-lasting solutions. Judea was also under strict governance with a militia that often used violent forces against any group of people that responded with violence. The militia in Son of Man carried out the programme of fear and intimidation to suppress the liberation efforts of the people. The Jesus movement operated discreetly in small groups before it became public. Jesus would say to a small group of people 'we must not be a suspicious group. We must believe in the inherent goodness of man. Together we shall lead ourselves, be it to glory or to destruction'. When Jesus addresses a larger crowd for the first time, the militia approaches the crowd to disperse because it is an illegal gathering. When Peter picks up a stone to throw at the soldiers Jesus responds 'Do not do it. Put that stone down'. Although disappointed by the dispersement, Jesus attempts not to lose his calm.

Jesus is arrested, taken to an isolated place and tortured. Jesus is told to join the elders so that they may share power. Jesus responds 'it is no good trying to beat me into agreement, it would not work'. These are similar to the words that Biko used when he was interrogated by the police: 'do not try any form of rough stuff, because it just would not work' (Biko 1978:173). A Biko Christ-figure does not want to give in to fear and intimidation. They stay true to what they believe in and become unhelpful to the interrogators. Jesus does not fight back but remains unhelpful. Biko wanted to be tied in order for him not to fight back by saying 'you have got to handcuff me and bind my feet together, so that I cannot respond. If you allow me to respond, I am certainly going to respond' (Biko 1978:174). A Biko Christ-figure knows that they would die for what they stand for but have to overcome the thought of their own personal death. The ability to be fearless of death becomes a victory. Jesus uses the words of Biko when he is told 'I will kill you' and responds 'how long will it take you?' (Biko 1978:174). A Biko Christ-figure is committed to the cause of social justice even to death.

\section{Ideology}

A Biko Christ-figure is not keen on addressing personal morality but is focussed more on institutional morality. Black Christians during apartheid South Africa were preached a message of self-condemnation and blaming oneself for misfortune. It made black people point the finger to themselves rather than the oppressive system of apartheid. The emphasis was on personal morality rather than the structural morality of apartheid. Although personal morality is also important; the landlessness of black people, mass poverty, unemployment and inadequate living conditions are not because of personal sin but structural sin. Biko (1978:61) states that stern-faced ministers stand on pulpits every Sunday to heap loads of blame on black people in townships for their thieving, housebreaking, stabbing, murdering, adultery and so on. No one ever attempts to relate all these vices to poverty, unemployment, overcrowding, lack of schooling and migratory labour. Jesus in Son of Man was very frank about this when preaching to a small crowd in a house:

we are too busy with moral trivialities, as if they are the most important things. If you constantly find fault with yourself, you will lose the struggle against real sin. All authority is not divinely instituted. If you follow me we will have peace. (Son of Man 2006)

A Biko Christ-figure prioritises the core of the societal problems that are not God's will but man-made. The problems in the township were not created by black people but by white people who were greedy economically and institutionalised the poverty and land dispossession there.

A Biko Christ-figure understands that there was a history of colonisation and a distortion of that history by imperialists especially when it comes to the current problems of Africa. Jesus in Son of Man preaches to a small group that:

when those with imperial histories pretend to forget them, and blame Africans' problems on tribalism and corruption while building themselves new economic empires, I say we have been lied to. Evil did not fall. (Son of Man 2006)

A Biko Christ-figure understands that Europe stands today because Africa was plundered of its resources and Africans dispossessed. Jesus in Son of Man knew the importance of land and emphasises it on two occasions as a child and as an adult. In the first scene as an adult, Jesus is tempted by the devil who promises him the world if he worships him but Jesus pushes Satan away telling him to get behind him and proclaims eli lilizwe lami 'this is my land/world'. The second instance as a child, when children were massacred, Jesus is given an opportunity by the angel to flee with him but Jesus refuses and says this is his land or world. Jesus in the New Testament was born in first century Palestine which was under the occupation of the Roman empire. Occupation is central to the life of Jesus in the New Testament, in Son of Man, and the context of Steve Biko. Maimela (1999:173) also indicates that Biko was given an emigration opportunity by officials of the United States of America but refused because 
he did not want to collaborate with those governments which, directly or indirectly, continued to facilitate the survival of the apartheid regime even though he knew his life was in danger. There is a sense of commitment to the land, an attachment. Poverty, unemployment and overcrowding in Africa are a product of colonialism.

A Biko Christ-figure values humanity and expresses principles of humaneness towards others. Biko (1978:51) states that the great powers of the world may have performed wonders in giving the world an industrial and military look, but the great gift still has to come from Africa - giving the world a more human face. A human face is that of grace, mercy, love, kindness and care. Jesus upholds that 'each human is important' and material should not have more value than the life of a human being. When the adulterous woman is chased in the streets and caught by community members who want to set her alight and stone her because she is a 'whore, spreads disease and corruption', they ask Jesus if they should punish her or not. The militia disperses the crowd and Jesus asks the woman where her accusers are? She responds, 'they are gone'. Jesus tells her to go because he does not accuse her. A Biko Christ-figure believes in the inherent goodness of man. Community takes precedence over the individual because many things can be achieved through unity and solidarity. When the unrest is intensified and the government imposes Marshall law on the community 'to restore peace we must use force'. Jesus and the disciples stand in solidarity with the women who protest outside the governmental building about the killings of their children.

A Biko Christ-figure has a view about how integration should work. In the film, it is in the form of an 'interim government' which is the sharing of power with the occupiers. A liberal idea of integration is living together (black and white) and sharing the same human rights with no segregated public spaces. A Biko Christ-figure accepts integration when it is according to the standards and conditions of the African. In the South African context, integration should be based on the African way of life and European settlers could be accommodated in such a society. Jesus responds to the elders in the film when told not to destabilise the negotiations towards an interim government 'interim government? It is designed to create a sense of false hope to make people believe something is being done'. The response of Jesus suggests that integration without the retribution of past economic injustice is not valid. Biko (1978:70) states that in reality, the artificially integrated circles are a soporific to the black people while salving the consciences of the guiltstricken white. The liberal does not take colonialism and land dispossession into cognisance. Its rhetoric is 'let us move on and not be stuck in the past'. The black person will have human rights and enjoy being in previously European-only public spaces but no rights about having their own land back which would lead to their economic liberation. When Jesus in the film is told that he is just a tiny minority and they will not allow him to upset the process of an interim government, Jesus responds, 'No group possesses the monopoly on truth and intelligence. The occupiers need a man like you (referring to the elders) to ease their conscience'. Integration should not be meant to appease the conscience of the white liberal but it should be genuine and just.

\section{Disappearance and death}

Zwick (2011) states that during the white terror regime, it was common to beat anti-apartheid activists to death and secretly dispose of them somewhere. Thus, it was a crucial part of the resistance to unveil the atrocities and accuse the regime by keeping the missing dead alive through a public display of photographs or even the dead bodies which were found. Giere (2011) asserts that disappearance here is located in the political reality. While there is not a white face in the whole of the film, the film is a commentary on the era of apartheid or its residue. Many people 'disappeared' during apartheid; the whereabouts of some were made known through the Truth and Reconciliation Commission in 1996 but others are still unknown till this day. Jesus was realistic on what was happening when activists 'disappear' but he was also prophetic on what will happen to him 'when you are told, and you will be, that people "disappear" you must say we have been lied to and evil will fall'. Jesus takes up the narrative of Biko, his abduction, 'disappearance', torture and death. The filmmaker says those particularly familiar with Biko's death will notice that 'Son of Man's Jesus is carried to his grave in a truck, known in South Africa as a bakkie, similar to the one that transported Biko' (Zwick 2011).

In the film, Jesus dies from torture during interrogation, buried and shot several times for certainty of his death. Mary and the community make their way to interrupt a speech by the occupier to find out what happened to Jesus of which the government denies being involved in his disappearance. Mary is told at the night vigil about the death of Jesus and where he was buried. Mary exhumes the body of Jesus and places him on the cross at night for all in the community to see. This indicates making known to the community what happened to Jesus when he 'disappeared'. Biko's death which was claimed from a 'hunger strike' is similar to Jesus' prediction that people should not believe that people just 'disappear', 'we have been lied to and evil will fall'.

Biko's death caught the attention of the international community, which increased the pressure on the South African government to abolish its detention policies and called for an international probe on the causes of Biko's death. Evidence presented during the 15-day inquest into Biko's death revealed that during his detention in a Port Elizabeth prison cell, he had been chained to a grill at night and left to lie in urine-soaked blankets. He had been stripped naked and kept in leg-irons for $48 \mathrm{~h}$ in his cell. A scuffle with security police caused brain damage. He was then driven, naked and manacled in the back of a Land Rover, to Pretoria. He died in a cell unattended on 12th September 1977 (SAHO 2016).

The public display of the body of Jesus on the cross and Biko's body on the media became an awareness of how brutal the system was to whoever challenged it. A Biko Christ- 
figure becomes a symbol of bravery, courage and standing for social justice no matter the consequences. The death of a Biko Christ-figure is not that of defeat but victory, because he does not give in to intimidation and becomes as unhelpful as possible to the authorities. The death of a Biko Christ-figure gave renewed energy of bravery and fearlessness to Mary and the community members of Judea. Mary and the community members protest around the body of Jesus and come in direct confrontation with the militia. Even when the militia made warning shots, Mary and the community members were not intimidated and continued to protest. The film expresses the important role women play in the struggle for liberation which is often overlooked. Mary led the community in protest and becomes the heroine of the film.

\section{Black Christology and Son of Man}

Simon Gqubule (1974), one of the first generation black theologians in South Africa, recalls his experience and analysis when watching films about Jesus and relating it to black theology. We thus quote him at length:

I remember how, some years ago, I was horrified by a religious film in which Jesus was made to speak with an American accent. His gestures, movements and his whole attitude seemed to me to be American. I went home feeling that this was horrible, how can Jesus be depicted as an American? As I thought further on this experience, it occurred to me that in films when Jesus was presented as speaking with an English accent I had never questioned this, because I had grown to accept it as such. If Christ could speak English with an English accent why should he not also speak with an American accent? If he is to speak to the American in his situation then he must speak to the American in an accent which the American will recognise as his own. In the same way if Christ is to be relevant to the Black man he must speak with the accent of a Black man, through the life experiences of the Black man, reacting to life situation in ways that would be recognisable to the Black man as his own. This is the essence of what is called Black Theology. (p. 18)

Gqubule acknowledges the universality of Christ and asserts that black theology is not an attempt to localise Christ but to make Christ relatable to the black experience. W.E.B. Du Bois (1903) in The Souls of Black Folk maintained that the problem of the 20th century is the problem of the colour line - the relation of the darker to the lighter races of men in Asia and Africa, in America and the islands of the sea. The colour of the skin has been an issue of debate for centuries, even so, there is no scientific evidence that a race possesses the monopoly of intelligence, truth and beauty. Somehow, it has been socially constructed to suggest that a race can be superior and another one inferior. Kelley (2002) in Racializing Jesus: Race, ideology and the formation of modern biblical scholarship contends that the west developed a racialised philosophy which influenced a racialised biblical scholarship. It is therefore important for blackness to be taken seriously and for black theology to participate in the debate and articulate a way of analysing films, especially a film about a black Jesus in the black experience.
McGrath (2011:265) states that Christology is the Christian doctrine of the person of Christ. The classical Christian account of the significance of Jesus of Nazareth is framed in terms of the concept of the 'incarnation' and the doctrine of the 'two natures' of Christ - divine and human. The nature of Jesus Christ was highly debated by the early church which was only in the Council of Chalcedon in 451 that there was an acceptable way of describing Jesus as 'truly divine and truly human'. Dwane (1977:4) asserts that the Council of Chalcedon in AD 451 did not formulate a creed of its own, but merely assigned to itself, the humble role of defending and upholding the Nicene faith. Dwane examines the ideas of Athanasius from the Alexandrian school of thought as he was the chief architect of the Nicene teaching. Athanasius articulates that salvation is divinisation. Only God can provide salvation to the created as the Creator and salvation finds man wherever he is. Christ is the one that mediates salvation from God to man which would make Christ fully divine. This Christology is based on eternity, on how Christ reconciles us to God. The incarnation of Christ is the reversal of the fall of man in Genesis and in order to be restored, Christ deifies us into himself in order for us to be saved.

Dwane (1977:8) critiques the Alexandrian soteriological principle of divinisation because it is a promise of a pie in the sky for many black people. It implies that it is foreign from addressing the black experience in that it is directed to salvation of souls. Dwane (1981:30) explains that liberation theology is theocentric and soundly biblical in so far as it points out that God does not luxuriate in God's eternal bliss, but reaches out to man and to the world. Dwane holds the view that Athanasius' Christology ignores the beauty of all creation and puts emphasis on the man's soul. If God is the Creator, then the entire cosmos should be redeemed. This contradicts the notion of community within the Bible as well as within the African community and takes a western stance of individualism. Black theology identifies with the Jesus that was born poor, humiliated and suffered and his message focussed on liberation to the poor. This is often ignored in western theology which is concerned with the middle and upper class man in the developed society. The life of Jesus Christ is relatable to the black experience, a people who find themselves dehumanised, dispossessed, marginalised and oppressed. Dwane (1977:10) states that we must rediscover the humanity of Jesus, and the fact of his poverty led to a new understanding of his work of salvation as liberation and humanisation. For the black person, this is not individualistic but communal to the black experience which requires 'radical liberation from all misery, all despoliation and all alienation'. Jesus Christ affirms our humanity and dignity. When we consider Simon Maimela's ontology and symbolism of black theology which ontologically refers to the experiences of black people and symbolically refers to every human being who is either marginalised, subjugated, oppressed and enslaved under the ruling elite (Tshaka \& Makofane 2010:532). Dwane (1981:31) implies that symbolically from a biblical perspective, God is the Father of the fatherless, the husband of the widow, and the One who sets at liberty those who are captives. Liberation theology is here to remind the church 
that through God's exercise of God's power and sovereignty over the creation which he loves with steadfast love, both the oppressor and the oppressed are set free, and brought to the liberty of the sons of God wherein the masks and the partitions of the Old Babel are demolished and the new humanity is born. It reminds the church of the Cross, and that in consequence of it, there can be no cheap reconciliation. Dwane relates Christology specifically to apartheid in South Africa that in order to be a new Christian community, the white person must be free from possession, love of comfort which makes them ignorant to look beyond their security and self-interest but to die to all forms of racial prejudice. The black Christian should equally be liberated from the hatred of the oppressor that seeks revenge in the quest for justice, self-pity, bitterness and seek God's healing and ability to forgive when radical change comes.

Moving from the ontology of black theology as suggested by Simon Maimela to address the particularity of the black experience, we turn to Takatso Mofokeng's (1983) The Crucified among the Crossbearers: Toward a Black Christology, who reverses the starting point of classical Christology which begins with the Bible and then the human experience to the black experience and then the Bible. The Christological question comes from Jesus Christ himself when he asked his disciples 'who do you say I am?' (Mt 16:15; Mk 8:29). Mofokeng's reverse question is created, provoked and guided by the 'anthropological' question of the oppressed black South Africans who struggle for liberation: 'who does Jesus Christ say that we are and how shall we become ourselves, our liberated selves?' This question deepens the struggle of the black people and their encounter with Christ in order to rediscover their true humanity and dignity. The question is a historical process of liberation in the midst of historical oppression.

Black Christology is thus liberation from the present moment of inhumanity and in the future glory of the coming of Christ. Mofokeng (1983:228) reflects on the words of Allan Boesak that man was created by God to be a creator and he has been given power which he has to utilise creatively in himself (self-identification) to nature and for sustenance and promotion of fellowship amongst people. Humanity and power are thus correlated, 'to share power and to share in power is to be fully human' and 'to be denied power is to be denied the right to be human'. And as the world in which man lives is organised, man shares in and utilises power in the entire socio-economic and political dimensions to express, to live and to achieve his God-given humanity. During apartheid, the black person shared no power in his own life and everything around him. There was no freedom of selfdetermination in all spheres of life but his socio-economic and political life was decided for him without his input. Embracing blackness was an act of violence and affirming their black humanity was an act of treason. Oduyoye (1995:7) critiques black theology that all the varieties of Christianity in Africa are riddled with androcentrism and misogyny. For women to be at home in Christianity, they suspend belief that it is androcracy that dominates them and not the will of God or their own special innate sinfulness arising out of being women. These challenges attribute to the silence of Christianity in Africa on the oppression, violence and marginalisation of women. African women are thus oppressed thrice; being an African, being a woman and being a Christian. Black theology should explicitly seek liberation for black women in the quest for liberation in totality.

In order for the black humanity to be realised, their liberation to be holistic and to have the power of self-determination, there are three things that need to be discussed. Mofokeng (1987:7) mentions that the interlocutor of Black Christology necessitates the inclusion of black history, black culture and land in Christological reflection as elements that inform the self-understanding of the black community, continuously and rapidly transforms its quest as well as enlighten its reading of Scripture.

\section{Black history}

Mofokeng (1983:235) states that Jesus Christ is the Lord of history and time by virtue of being raised by the Father to live eternally and reign eternally in the world, and is the first and last word of black people's life and praxis. This means that Jesus Christ still lives amongst the oppressed, stands in solidarity with the poor, preached the kingdom of God and was crucified and accepted the cross and death as the final act for the dehumanised. Mofokeng (1987:7) asserts that we have to go further and affirm his presence and victorious activity in our past, including our distant African past. As Jesus Christ traversed the way from Bethlehem to Golgotha, creating new black men and black women in our African past, they were converted to him and to a liberative praxis in their time and world. African 'founding fathers' were fighting for liberation from colonialism and imperialism. Names such as Shaka, Moshoeshoe, Sekhukhuni, Hintsa, Makana and others continued the liberation praxis of Jesus Christ in their time. Biko (1978:32) emphasised the importance of rewriting the black history and to produce in it the liberation heroes who form the core of the African background. An important note in rewriting black history is to resuscitate African women who are silenced yet played a role in the liberation of Africans. A rewritten black history would become the counteraction towards the disfigured, distorted and negative black history portrayed by imperials. The people who are not aware of their history or who learn a distorted one produced by imperials will despise African history and its heroes and when that happens, there would be no sense of black pride.

Gqubule (1974:17) clarifies that Christianity is not a white man's religion but it just happens that Christianity was brought to South Africa by white missionaries. The white people (Greeks, Romans, Spaniards, French, Germanic tribes, Britons, etc.) were converted from their pagan religions to the Christian faith just like many other nations. The negativity of Christianity in South Africa during colonialism was that it was the religion of the same coloniser and during apartheid was how it was used to systematically oppress and marginalise Africans. There is thus nothing 
wrong with Christianity but everything wrong with how it is interpreted by people to justify subjugating a nation through its application. It has been said that first, there was the missionary, then a trader and then the conqueror. Steve Biko asserts that the first people to come and relate to black people in a human way in South Africa were the missionaries (Biko 1978:103). Even so, their missionary approach was invasive, demonised African religion and confused the people with their new religion. As a matter of fact, the first coloniser came in 1652 and then the first missionary came in 1737. Oduyoye (1989:195) acknowledges the importance of African culture and that individual elements of each and every culture and tradition are to be purified or enhanced by the Gospel. Missionaries that came to Africa could only see African culture and tradition as idolatry. It is important to note that Oduyoye does not reject African culture completely but seeks to embrace African culture and 'purify' elements that marginalise and are oppressive especially towards women. There was always a difference between the attitude of the missionary to the black man and the attitude of the colonists. Even so, Christ was ever present in the black history of South Africans. The many black heroes that resisted white domination were doing so in the presence of Jesus Christ while creating, evoking and empowering a corresponding liberative undercurrent in our African history (Mofokeng 1987:7).

Mofokeng (1987:8) asserts that this history of black suffering at the hands of white racists and capitalists who subjected black people of all shades to inhuman oppression and merciless exploitation could not but provoke black Christians of the past to translate this experience into theological and religious questions. It was this very struggle that inspired the Exodus from white churches to establish African initiated churches (AICs). It was this very struggle that inspired black Christians to critically analyse the black experience through lens of the Scripture and developing black theology. It was understood that God is the God of the Exodus, he hears the cries of black pain and will liberate them from oppression and marginalisation. The African Christians who were before us fought for their human dignity and land that was taken from them. Mofokeng (1987:8) states that as a matter of fact, it is these liberative elements in the wide and deep pool of black history that have verified the truth of the Christian message of salvation and consequently sustained the faith of our Christian forefathers. It is noted that black history is not only limited to the battles our Christian forefathers and mothers fought to liberate themselves from imperialism, but there is also general history that includes many other subject matters that are not in alignment with Black Christology. Just like many other cultures in different nations, there are both positive and negative elements within a culture.

\section{Black culture}

Tlhagale (1985:27) explains that culture has various different definitions but can be broadly defined as 'a way of life' that expresses meanings and values embedded in institutions and in human behaviour; culture is also understood in terms of literary and artistic works. In this section, we look into culture as an expression of meanings and values. The South African context gives a peculiar perspective of culture considering South African history. During colonisation, African culture was regarded as pagan therefore needed to be replaced with Western (civilised) culture. Westernisation of the African began threatening the political and economic well-being of the dominant (Anglo-Boer) groups. Apartheid saw the convenient recognition of the existence of the difference in ethnic nature, ethnic custom, ethnic development and civilisation. Separate development was then aimed at retaining political power amongst the white people and preventing economic competition with black people. Biko (1978:44) states that somehow Africans are not expected to have any deep understanding of their own culture or even of themselves. Other people have become authorities on all aspects of the African life or to be more accurate on Bantu life. This implies the inability for self-determination and selfpreservation. Also, meaning that the Bantu is not capable of being a human without the guardianship of other cultures. Even the response to the experience of the Bantu life was monitored and even channelled on how to appropriately respond to their oppression.

According to Mofokeng (1987:9), black culture in its visible and invisible, material and immaterial, audible and inaudible forms is the net result of black experiences and creative efforts as black people eke out existence from oppressed nature under the scotching heat of the sun. Black culture is thus the expression of the black experience. In the apartheid context, it is the expression of oppression, survival and resistance. Resistance to economic, political and cultural oppression is referred to as the black culture. Biko (1978:50) calls it the modern black culture, a culture of defiance, selfassertion and group pride and solidarity. This is a culture that emanates from a situation of common experiences of oppression. It is also a culture that is responsible for the restoration of our faith in ourselves and therefore offers a hope in the direction we are taking from here. This expression is evident in our music, dance, art, dress code and lingo amongst others.

The black culture emerges in the midst of dehumanisation, oppression, marginalisation and racial discrimination. It seeks to affirm the black human dignity in the midst of domination. As long as there is oppression of the blacks in any form, there will be resistance. Mofokeng (1987:9) asserts that as long as the vanquished black people still exist and are not exterminated by a total genocide, they will retain the memory of freedom hidden in the dark corner of their subconscious. This memory keeps the spirit of liberation at heart and encourages those who give in to rise up. Liberation by any means necessary is legitimate as freedom is a basic human desire. Mofokeng (1987:10) relates the resurrection of Jesus Christ to be in continuous solidarity with the oppressed black people in their struggle to free themselves to become children of God and brothers of Jesus. This implies that the black brothers of Jesus Christ produce a liberating culture in struggle which, in turn, dynamises and energises their 
exodus of hope, then we should be confident that God accepts their culture as his instrument. The black culture is thus a necessity and the will of God for the black oppressed.

\section{Land}

Jesus in Son of Man declared 'the is my world [land]' when the angel offered him an escape from violence. Jesus committed himself to staying in the land of his birth and to resist oppression from those who occupied the land of his birth. The struggle for freedom in South African history has always been connected to the recovery of stolen indigenous land. This struggle emerges when the black South Africans became foreigners in their own land. The land question is one of the most sensitive issues to engage on in South Africa as there are different historical accounts which will not be engaged at length but we will analyse how Mofokeng relates land as one of the Christological themes for black theology. Mofokeng (1987:11) explains the significance of land for black people: (1) land is the mother and we are the sons and daughters of the soil; (2) it is not sufficient to regard land only as a means of production in a narrow sense, it is more than this; (3) land gives black people an identity and, in turn, receives an identity from them; (4) land is the source of livelihood for Africans and has to be cherished and cared for; (5) our land is the source of individual and communal health; (6) land is of religious significance as there are locations of sacred places in the mountains, ponds, streams and bushes; (7) the land is socially and psychologically significant as a locus for our habitation, where we sink our roots and derive our freedom to move around the country freely; (8) the land is the bedroom where we put our departed loved ones to bed; (9) it is the house of our ancestors where we go and dialogue with them because without them, we lose our sense of continuity and history; and (10) there is an emotional bond to the land of our birth. The emphasis lies in the fact that without the land, there is emptiness within the African who ends up becoming a wanderer with no roots. Mofokeng (1983:232) relates the African dispossessed with the Old Testament Israelite wanderers. The God of the Israelites, the creator of his people for himself as well as the owner of land, promises and eventually gives the land - Canaan - as his saving act for his people. The critique about this is that it justifies land invasion that the oppressors in the South African context used to take land from the African natives. The same concept does not apply when African natives seek their land back. It also does not need scriptural justification for Africans to seek their land back. Mosala (1996:18) attests that the rest of the history of the biblical communities from the Davidic and Solomonic monarchical era to the Babylonian exilic period and the subsequent New Testament time under Roman rule has been the history of the struggle over land. Wealth and poverty in the biblical experience are a consequence or result of ownership or lack of ownership of land. The wealth or poverty of South Africans depends on the ownership or non-ownership of land.

It has been said before that South Africa is a capitalistic society within a democracy. The first question that arises on the subject of land is what will black people do with the land or would the economy of South Africa grow if the land is in black hands? The significance of land to Africans has already been given by Mofokeng, that it is more than a means of production. Mosala (1989:36) gives an approach from the premise that there is no such thing as a politically and ideologically neutral reading of the Bible; hence, liberal scholarship has spent much sweat trying to prove that Jesus was not a revolutionary. Mosala maintains that unless Christians are socialists, they cannot be Christians. Before there was capitalism, people produced what they needed and if they produced more than they needed, they exchanged with somebody else for something they wanted. Capitalism, on the other hand, is an exploitative system that cares more about profit-making than the well-being of people and land. It produces for exchange and not for use. It turns labour into a commodity which can be sold and bought and thrives on unemployment, as poor and desperate people are willing to do any job at any pay. South Africa has a majority of black people who are landless, poor and unemployed. They find themselves in a system that exploits and dehumanises them because of desperation. This has been happening since colonialism and it still happens in a post-apartheid democratic society.

Mosala (1989:34) argues that socialism is also a biblical concept because socialism is the social ownership of the means of production that would be production first and foremost for meeting human needs. Mosala (1987:27) mentions that means of production refer to land, cattle, trees, rivers, tools, machines and so on, plus human labour. Mosala (1996) points out that Micah 4:3-4 is probably the only real socialist part of the Bible:

... They will beat their swords into ploughshares, their spears into pruning knives ... Each man [sic] shall sit under his vine, under his fig tree; and no one will be terrorised, for the mouth of Yahweh of hosts has spoken. (p. 18)

In other words, land should not be owned by a few individuals to enrich themselves and keep widening the gap between the rich and poor but it should be owned by the people in order to close the gap of inequality and prevent the exploitation of people. Mofokeng (1983:234) agrees that socialism would be a community of people who share equally the toil for life and the fruits of their communal toil.

The reverse Christological question 'who does Jesus Christ say that we are and how shall we become ourselves, our liberated selves?' is answered when the black community is understood through their black history, black culture and land. In order to 'become ourselves, our liberated selves', we must continue with the total emancipation of blackness. An alienation from these essential things is being distant to the very ontology of being black. The task of the present generation is therefore to continue the liberation praxis which was started by the African 'founding fathers'. Mofokeng (1987:12) states that it is for this that Black Christology cannot ignore the issue of land as informer and transformer of Christological thought. He is convinced that it will deepen Christology and expose the wealth of materialistic readings of, especially, the Gospels. 
The article suggests that the life of Jesus in Son of Man cannot be understood without reference to the life of Steve Biko (nonviolence, ideology and disappearance and death) and the Christology in Son of Man cannot be understood without reference to Mofokeng's Black Christology (black history, black culture and land). Steve Biko thus takes on a Christfigure image in regard to Mofokeng's Black Christology. It is not the first time that Steve Biko is referred to as a Christfigure in art. Hill's (2015) Biko's Ghost: The iconography of Black Consciousness traces the artistic representation of black consciousness, including messianic representations of Biko. Son of Man further contributes to the iconography of black consciousness as well as Black Christology in arts. Hill (2015:33) attests that an important series of prints called Black Crucifixion also appeared in 1976. Black theology, a socioreligious ideology that shares numerous tenets with Black Consciousness, and by the mid-1970s 'New Testament themes were energetically employed in the re-picturing of Christ as an oppressed victim struggling to free himself'. Christ is a black man in this series, which conflates the traditional rendering of his Passions with the manacles and jail cells familiar to black South Africans at this time.

\section{Conclusion}

Mofokeng's Black Christology constructs a Steve Biko Christfigure in the Son of Man film. Black theology identifies with the Jesus who was born poor, was humiliated and suffered, and his message focussed on the liberation to the poor. Mofokeng reverses the Jesus' Christological question 'who do you say I am?' into 'who does Jesus Christ say that we are and how shall we become ourselves, our liberated selves?' This question deepens the struggle of the black people and their encounter with Christ in order to rediscover their true humanity and dignity. Oduyoye emphasises that African women also encounter Christ who is in solidarity with women oppression in African culture and African Christianity. A Steve Biko Christfigure does not discriminate based on age, race and gender but is in solidarity and seeks to liberate everyone that is oppressed, and black people in particular. A Steve Biko Christ-figure understands that subjugation and the cause of poverty are institutional and not based on personal immorality. A Biko Christ-figure is committed to non-violent means to achieve the goal of liberating minds of the oppressed and dismantling the institutions that cause the oppression. Mofokeng's Black Christology is realised in the Son of Man film and the study of arts in black theology should be harnessed for the continuous relevance of black theology in post-apartheid South Africa.

\section{Acknowledgements Competing interests}

The author declares that he has no financial or personal relationships which may have inappropriately influenced him in writing this article.

\section{References}

Biko, S., 1978, I write what I like, Picador Africa, Northlands.

Chattaway, P.T., 2006, Son of Man gets people talking, Film Chat with Peter T. Chattaway, viewed 28 January 2016, from http://www.patheos.com/blogs/ filmchat/2006/02/son-of-man-gets-people-talking.html

Du Bois, W., 1903, The souls of black folk, Oxford University Press, Chicago, IL.

Dwane, S., 1977, 'Christology in the third world', Journal of Theology for Southern Africa 21, 3-12.

Dwane, S., 1981, 'Christology and Liberation', Journal of Theology for Southern Africa $35,29-37$.

Giere, S.D., 2011, 'This is my world!' Son of Man (Jezile) and cross-cultural convergence of Bible and World', Journal of Religion and Film 15(1), 1-5.

Gqubule, S., 1974, 'What is Black Theology?', Journal of Theology for Southern Africa $8,16-23$.

Hill, S.L., 2015, Biko's Ghost: The iconography of Black Consciousness, University of Minnesota Press, Minneapolis, MN.

Kelley, S., 2002, Racializing Jesus: Race, ideology and the formation of modern biblical scholarship, Routlegde, London.

Maimela, M.R., 1999, 'Black Consciousness and white liberals in South Africa: Paradoxical anti-apartheid politics', Doctoral dissertation, University of South Africa. McGrath, A.E., 2011, Christian Theology: An introduction, Wiley-Blackwell, London.

Mofokeng, T.A., 1983, The Crucified among the Crossbearers: Toward a Black Christology, Uitgeversmaatschappij JH Kok, Century.

Mofokeng, T.A., 1987, 'Black Christology: A new beginning', Journal of Black Theology in South Africa 1(1), 1-17.

More, M.P., 2004, 'Albert Luthuli, Steve Biko, and Nelson Mandela: The philosophical basis of their thought and practice', in K. Wiredu (ed.), A companion to African philosophy, pp. 207-215, Blackwell Publishing, Oxford.

Mosala, I.J., 1987, 'Black theology versus the social morality of settler colonialism: Hermeneutical reflections on Luke 1 and 2', Journal of Black Theology in South Africa 1(1), 26-42.

Mosala, I.J., 1989, 'Christianity and socialism: Appropriating Moses and Jesus for national liberation in Azania', Journal of Black Theology in South Africa 3(2), 28-37.

Mosala, I.J., 1996, 'Wealth and poverty in the Old Testament - A black theological perspective', Journal of Black Theology in South Africa 5, 16-22.

Oduyoye, M.A., 1989, 'Alive to what God is doing', The Ecumenical Review 41(2), 194-200.

Oduyoye, M.A., 1995, 'Christianity and African culture', International Review of Mission 84(332-333), 77-90.

Reinhartz, A., 2007, Jesus of Hollywood, Oxford University Press, New York.

SAHO, 2016, The inquest into Biko's death and his funeral, South African History, viewed 13 March 2017, from http://www.sahistory.org.za/article/inquest-bikosdeath-and-his-funeral

Thagale, B., 1985, 'Culture in an apartheid society', Journal of Theology for Southern Africa 51, 27-36.

Tshaka, R.S. \& Makofane, M.K., 2010, 'The continued relevance of Black Liberation Theology for democratic South Africa today', Scriptura 105, 532-546.

Zwick, R., 2011, 'Between Chester and Capetown Transformations of the Gospe in Son of Man by Mark Dornford-May', Journal of Religion and Film 15(1), viewed 22 April 2016, from https://www.unomaha.edu/jrf/Vol15.no1/ ZwickTranforms.html 